
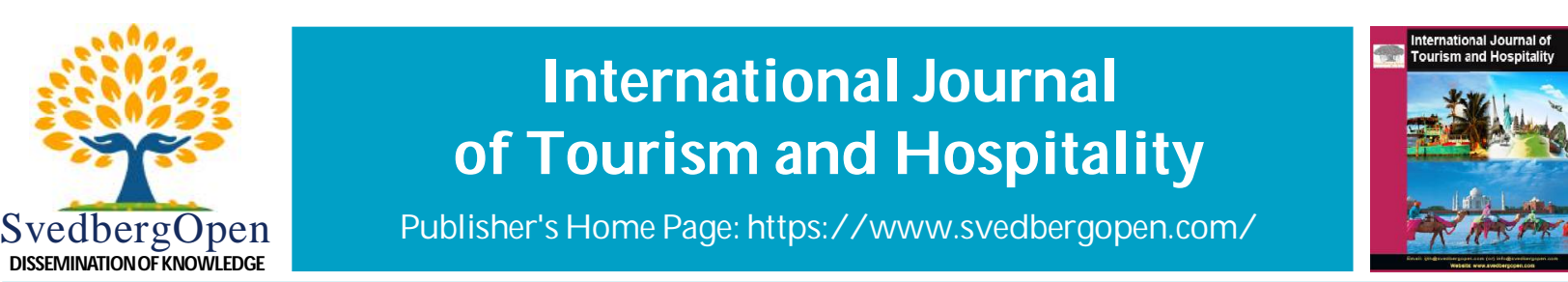

Research Paper

Open A ccess

\title{
Impact of Covid-19 on tourism sector of Asia and Pacific countries evidence from 20 Asia-Pacific countries
}

\author{
Deyshappriya, N.P.R. ${ }^{1 *}$, U.G.O. Sammani ${ }^{2}$ and R.W.V.K. Minuwanthi ${ }^{3}$ \\ ${ }^{1}$ Senior Lecturer in Economics, Faculty of Management, Uva Wellassa University of Sri Lanka. E-mail: ravindra@uwu.ac.1k \\ ${ }^{2}$ Lecturer in Tourism Studies, Faculty of Management, Uva Wellassa University of Sri Lanka. E-mail: sammani@uwu.ac.lk \\ ${ }^{3}$ Undergraduate students, Faculty of Management, Uva Wellassa University of Sri Lanka. E-mail: koshilaminuwanthi@ gmail.com
}

\section{Article Info}

Volume 1, Issue 2, April 2021

Received : 19 January 2021

Accepted : 22 March 2021

Published : 05 April 2021

doi: 10.51483/IJTH.1.2.2021.1-11

\begin{abstract}
The present study examines the impacts of COVID-19 on tourism industry in 20 countries of Asia and Pacific region, highlighting the effects on international tourist arrivals and tourist receipts, air reservation, hotel bookings and occupancy rates. As the results indicate, Asia and Pacific region reported the highest drop in tourist arrivals, which was $-9 \%$ in January, 2020 and dropped further down to $-98 \%$ by October, 2020. Drop in international tourist arrivals caused declining tourist receipts which is eight times higher than that of the global financial crisis in 2009. Apart from that, Asia and Pacific region reported the highest drop $(-96 \%)$ in flight reservation by November 2020 compared to the previous year. Similarly, the occupancy rate in 2020 has also declined from $55 \%$ in January to $27 \%$ by March. Moreover, drop in hotel bookings has reached a bottom during April and May of 2020 and drop was more substantial in the regions such as Africa, Europe, Middle East and Asia and the Pacific. Under this scenario, it is apparent that tourism sector of Asia and Pacific countries has been severely affected by COVID-19 and therefore alternative revenue sources should be explored till the tourism sector re-emerged.
\end{abstract}

Keywords: COVID-19, Tourist arrivals, Tourism receipts, Hotel bookings, Travel restrictions

(C) 2021 International Journal of Tourism and Hospitality. This is an open access article under the CC BY license (https://creativecommons.org/licenses/by/4.0/), which permits unrestricted use, distribution, and reproduction in any medium, provided you give appropriate credit to the original author(s) and the source, provide a link to the Creative Commons license, and indicate if changes were made.

\section{Introduction}

\subsection{Historical evolution of pandemics and Covid-19}

It is a well-known fact that communicable diseases has significantly shaped human history and will change in the future as well. Therefore, the present Covid-19 outbreak will not the be last pandemic and therefore it is important to examine historical aspect and outbreak of such pandemics and in turn countries will be able to take better precautionary for any possible crisis in the future. In fact, pandemic or epidemic implies an excessive widespread of disease in a geographical area. One of the key reasons related to occurrence of such pandemic is shifting toward agrarian communities where there is a frequent human-animal interaction. Similarly, rapid increase in international trade is one of transmission mechanisms of such epidemics and therefore epidemics such as Malaria, Influenza, Smallpox, Leprosy and Tuberculosis widespread across the globe.

\footnotetext{
* Corresponding author: Deyshappriya, N.P.R., Senior Lecturer in Economics, Faculty of Management, Uva Wellassa University of Sri Lanka.E-mail: ravindra@uwu.ac.lk
} 
Table 1 indicates the major pandemics that have occurred over time along with death toll and types.

\begin{tabular}{|c|c|c|c|}
\hline Name & Time period & Type / Pre-human host & Death toll \\
\hline Antonine plague & $165-180$ & Believed to be either smallpox or measles & $5 \mathrm{Mn}$ \\
\hline Japanese smallpox epidemic & $735-737$ & Variola major virus & $1 \mathrm{Mn}$ \\
\hline Plague of Justinian & $541-542$ & Yersinia pestis bacteria / Rats, fleas & $30-50 \mathrm{Mn}$ \\
\hline Black death & $1347-1351$ & Yersinia pestis bacteria / Rats, fleas & $200 \mathrm{Mn}$ \\
\hline New World smallpox outbreak & 1520 - onwards & Variola major virus & $56 \mathrm{Mn}$ \\
\hline Great plague of London & 1665 & Yersinia pestis bacteria / Rats, fleas & 100,000 \\
\hline Italian plague & $1629-1631$ & Yersinia pestis bacteria / Rats, fleas & $1 \mathrm{Mn}$ \\
\hline Cholera pandemics 1-6 & $1817-1923$ & V. cholerae bacteria & $1 \mathrm{Mn}+$ \\
\hline Third plague & 1885 & Yersinia pestis bacteria / Rats, fleas & $12 \mathrm{Mn}$ (China and India) \\
\hline Yellow fever & Late $1800 \mathrm{~s}$ & Virus / Mosquitoes & $100,000-150,000$ (US) \\
\hline Russian flu & $1889-1890$ & Believed to be $\mathrm{H} 2 \mathrm{~N} 2$ (avian origin) & $1 \mathrm{Mn}$ \\
\hline Spanish flu & $1918-1919$ & H1N1 virus / Pigs & $40-50 \mathrm{Mn}$ \\
\hline Asian flu & $1957-1958$ & $\mathrm{H} 2 \mathrm{~N} 2$ virus & $1.1 \mathrm{Mn}$ \\
\hline Hong Kong flu & $1968-1970$ & $\mathrm{H} 3 \mathrm{~N} 2$ virus & $1 \mathrm{Mn}$ \\
\hline HIV/AIDS & 1981 -present & Virus / Chimpanzees & $25-35 \mathrm{Mn}$ \\
\hline Swine flu & $2009-2010$ & H1N1 virus / Pigs & 200,000 \\
\hline SARS & $2002-2003$ & Coronavirus / Bats, Civets & 770 \\
\hline Ebola & 2014-2016 & Ebolavirus / Wild animals & 11,000 \\
\hline MERS & 2015-Present & Coronavirus / Bats, camels & 850 \\
\hline Covid-19 & 2019-Present & $\begin{array}{l}\text { Coronavirus - Unknown } \\
\text { (possibly pangolins) }\end{array}$ & $\begin{array}{l}248,200 \text { (Johns Hopkins } \\
\text { University estimate as } \\
\text { of 8:32am PT, May } \\
4,2020 \text { ) }\end{array}$ \\
\hline
\end{tabular}

As Table 1 indicates, there were huge number of death due to world-wide pandemics. The main reason is there was a traditional myth on spirits and gods inflicted such diseases and therefore there is no recovery from such diseases. Hence, such traditional myths and unscientific opinions led to catastrophic results accounting for millions of deaths. However, gradual improvement in education and healthcare sector have significantly reduced the death rate related to current pandemics and also occurred in the recent past.

Despite global health condition which has been supported by global agendas such as Millennium Development Goals (MDSs), Sustainable Development Goals (SDGs) and international organization such as World Health Organization (WHO) has improved considerably over past few decades, outbreak of critical illnesses cannot be fully controlled yet. Severe Acute Respiratory Syndrome (SARS) in 2003 and the Middle East Respiratory Syndrome (MERS) in 2012 can be recognized as epidemics in recent history and the most recent outbreak is new coronavirus disease which is known as 
Covid-19, was first identified in Wuhan, People's Republic of China (PRC), in early January 2020. As scientist confirmed, Covid-19 also belongs to the same family of coronaviruses which caused SARS and MERS in 2003 and 2012 respectively. However, mortality rate of Covid-19 is approximately $6.8 \%$ (as of $10^{\text {th }}$ of April 2020) which still is significantly lower than that of SARS (10\%) and MERS (34\%). Nevertheless, infection rate of Covid-19 (1.5\%-3.5\%) outnumbered that of SARS and MERS and also Ebola. The total number of confirmed cases of Covid-19 has been rapidly increasing in China initially and then rest of the countries as well. In fact, the confirmed number of cases has already surpassed the total of SARS and by the end of February, 2020 and currently there are 85,878,110 (as of $04^{\text {th }}$ of January 2021) confirmed cases across 212 countries with death toll of 1,864,461 (as of $04^{\text {th }}$ of January 2021). While the outbreak has been slowing in China, the confirmed cases have dramatically increased in countries such as USA, Italy, Spain, France and UK. Consequently, WHO has announced a global emergency condition.

\subsection{Asia and Pacific region - A background}

The Asia and Pacific or APAC region which is also known as AsPac has no clear-cut definition of "Asia Pacific" and the regions are varies depending on the context. However, it generally includes East Asia, South Asia, South East Asia and Oceania. The word grew in popularity in the 1980s as it was used to discuss on commerce, politics, and finance. In addition, APAC is also known (and less frequently referred to) as the region of APJ, which also stands for the region of Asia Pacific Japan. The word may also include parts of Russia (in the North Pacific) and countries in the Americas on the coast of the Eastern Pacific Ocean. For an example, Asia-Pacific Economic Cooperation includes Canada, Chile, Russia, Mexico, Peru and the United States. Alternatively, the word also encompasses both Asia and Australasia as well as Pacific island nations (Asia-Pacific and Australian continent). China is the largest country in the region, followed by Australia, India, Indonesia and Mongolia while Macau is the smallest. In fact, some of the most populous countries such as China (1.44 billion) and India (1.38 billion) are also located in the Asia and the Pacific region (World Population Review). The region is characterized by not only larger population and but also stronger economic growth than any other, a rich diversity of both socioeconomic and natural environment, and an abundance of natural resources including tropical rain forests and marine products. As a whole, the region has experienced remarkable growth over the last decades, accounting for more than 35\% of the world's Gross Domestic Product (GDP). Rapid development in the region has lifted millions of people from poverty. Despite this, the area is still home to some 700 million utter poor people. World Green Building Council mentioned that $60 \%$ of the world's population (4.3 billion people) currently live in the AsiaPacific region, with more than 2 billion living in urban areas. In fact, the region has 16 of the 28 mega-cities in the world (cities with 10 million or more population). The region also includes vast changes in climate and topography, from tropical to arctic, and from the Himalayas to coral reefs. In addition to its immense physical dimensions, the region offers a wide spectrum of historical, cultural and ethnic diversity, as well as a multitude of phases of political evolution and economic development.

\subsection{Objective and structure of the study}

The main objective of this study is to examine the impact of Covid-19 on tourism sectors in Asia and the Pacific regions. More specifically, the study attempts to examine impact of Covid-19 on tourist arrivals, tourism receipts, air reservation, hotel bookings and occupancy rates of the Asia and the Pacific region in general. Apart from that, specific changes in tourist arrivals and tourism receipts are also addressed considering 20 countries in the Asia and the Pacific region. The next sections of the paper include a brief literature review, methodology adopted followed by the results and discussion.

\section{Literature review}

\subsection{Impact of tourism sector on Asia and Pacific economies}

Tourism is a leading industry in the service sector at global level, as well as a major provider of employment and a major producer of foreign exchange at national level. Tourism has become one of the largest and fastest-growing sectors in the global economy. As the fastest-growing travel and tourism region, Asia-Pacific continues to increase its importance for the global industry. In 2017, it was also the second-largest destination for international tourists and the second-largest volume of international tourist receipts. In addition, the region is the largest source of global outbound tourism spending, most of which is spent on intra-regional travel. On the basis of GDP estimates, Asia-Pacific also has the highest aggregate domestic travel market (T\&T Competitiveness Index, 2019). The Asia-Pacific region, specified by the World Tourism Organization (WTO) as encompassing North-East Asia, South-East Asia and Oceania, is expected to be the 
primary focus of the global tourism industry in the $21^{\text {st }}$ century (Chen, 2011). The Asia Pacific region accounted for $25 \%$ of the total tourism arrivals of the world in 2018. Furthermore, 30\% ( $\$ 437 \mathrm{bn}$ ) of the total tourism receipts out of the total international tourism receipts $(\$ 1,463 \mathrm{bn})$ were generated by the Asia Pacific region in 2018. The share of tourism in service exports of the region in 2018 accounted for $31 \%$ out of the total service exports in the Asia Pacific region United Nation's World Tourism Organization (UNWTO).

According to Chen (2011), the region has been identified as one of the most promising markets for tourism demand and supply, with export earnings of $\$ 1,002$ bn and 124 million jobs by 2019, a phenomenon that will lead to positive economic growth and a rise in GDP. Increased employment opportunities, increased economic growth, decreases in political barriers, easing of travel restrictions and more successful tourism campaigns have been the key factors which drive the growth of tourism in the Asia-Pacific region. The Asia-Pacific region has become a popular travel hub for all types of tourists. Over the last decade, Asia Pacific has seen dramatic growth in domestic and international tourist arrivals, as well as increases in tourist receipts. The region has developed its reputation as an in-trend holiday destination, offering must-see attractions and idyllic, natural landscapes. Although an exciting travel opportunity for tourists, the tourism industry is vital to many developed and growing economies across the Asia-Pacific region, making significant contributions to various GDPs (Moor, 2020). Moreover Moor (2020), mentioned that as one of Asia Pacific's leading industries, it is unsurprising that the travel and tourism sector created more than 29 million jobs in China in 2019. Likewise, an astronomical number of jobs have also been generated in India, due to the travel and tourism industry, which has created an incredible 27.4 million jobs. Indeed, several Asia-Pacific countries have rated the world's highest number of jobs in the travel and tourism industry.

Tourism is one of the most significant sectors of the economy in Asia and the Pacific. Currently, tourism is the most important sector and main source of foreign exchange earnings in Thailand, Australia and New Zealand. It is ranked second in Hong Kong, Malaysia and the Philippines, and third in Singapore and Indonesia. Strong intra-regional tourism growth, supported by consistently growing disposable incomes, coupled with the constant growth of airline seat capacity to new destinations within the region, continues to be a key driver of Asia and Pacific tourism in the foreseeable future. Fiji, Singapore, China, New Zealand, Thailand, Malaysia, Vietnam or Singapore, tourism is a major employer for many citizens of all these countries but if managed sensitively can also present opportunities to nurture and showcase the cultural distinctiveness of each country in this vast and expansive region (Baker, 2013).

\subsection{Impact of Covid-19 on global and regional tourism}

In December 2019, the first cases of a new contagious disease were diagnosed in the city of Wuhan, the capital of Hubei province in China. Within a short period of time the outbreak developed exponentially into a pandemic that infected millions of people, with a global death toll of more than 500,000 during its first six months. Eventually, the novel disease was named coronavirus disease 2019 (Covid-19), and the new virus was identified as severe acute respiratory syndrome coronavirus 2 (SARS-CoV-2). Similar to all known pandemics throughout history, Covid-19 has been accompanied by a large degree of fear, anxiety, uncertainty, and economic disaster worldwide (Pitlik, 2020). As a result, asymptomatic people transmit Covid-19 before they know to self-isolate or take other measure like physical distancing in public and with limited testing in many countries, also due to the unavailability of tests, unknowingly asymptomatic transmission is thought to be substantive (He et al., 2020). The risk of epidemics or pandemics spreading is the most critical risk factor for a medical crisis. These rapidly spreading diseases interact actively with the international tourism system. On the one hand, tourism facilitates the spread of epidemics around the world due to high mobility; however, the outbreak of the epidemic also affects tourism. The latest pandemic, Covid-19, poses a gloomy scenario for all industries, but particularly the tourism industry, in terms of very low or no mobility (Uğ ur and Akb1r1k, 2020).

According to the Folinas and Metaxas (2020), the World Travel and Tourism Council (WTTC) warned that the Covid19 pandemic could cut 50 million jobs worldwide in the travel and tourism sector, and Asia is expected to be the worst affected. When the epidemic is over, it could take up to ten months for the industry to recover (World Economic Forum of the 2020). This effect will rely on how long the epidemic lasts and may also be intensified by recent restrictive measures, such as those introduced by the US administration on travel to Europe (WTTC, 2020). According to the Chief Executive Officer of WTTC, the coronavirus is a major threat to the tourism industry that could reduce the travel market by up to $25 \%$ by 2020. The International Air Transport Association (IATA, 2020) has predicted that coronavirus is expected to decrease global airline revenues by $\$ 29.3$ bn by 2020 as a result of a contraction in global air demand. Although this is the first such contraction since the 2008-2009 global financial crisis, it must be recognized that almost $95 \%$ of this estimated loss will be suffered by Asia/Pacific carriers. 
Tourism is an important source of revenue for many developing Asian economies, with international tourism receipts accounting for more than $40 \%$ of GDP in economies such as Palau and Maldives, and overall travel and tourism (including domestic tourism) exceeding 10\% of GDP in almost half of economies in Asian Development Bank participants. Importantly, Chinese visitors now make up a significant proportion of tourists in many of these economies, as the number of outbound tourists from the China increased 8-fold from less than 11 million in 2003 to close to 87 million by 2018. In 2018, tourists from the China accounted for more than a quarter of the total tourist arrival in Myanmar; Thailand; Mongolia; Republic of Korea; Viet Nam; Cambodia; Palau; and Hong Kong (Abiad et al., 2020). Tourism-related operations have also been adversely affected by internal processes. The recent spread of the virus (with or without state quarantine measures) has led to a marked decline in so-called "social consumption." Restrictions include visits to restaurants, domestic tourism, visits to cultural activities, trade fairs (Hoque et al., 2020). Several major events have also been delayed or even cancelled in many countries (Uğ ur and Akb1r1k, 2020). Coronavirus outbreak continues to severely restrict visitor numbers in Australia. Places such as Gold Coast or Cairns, which are among Australia's most popular destinations suffer a visitors reduction up to $90 \%$ and an important reason for this, is the fact that these destinations supported by large numbers of tourists from China, Japan, and South Korea (Folinas and Metaxas, 2020).

In a short period of time, some research has been conducted studies on the impact of Covid-19 on tourism. The vast majority of these research concentrate on the study of regional impacts. Dinarto et al. (2020), investigated the effect of the virus on the tourism industry in Bintan (an island in the Riau archipelago of Indonesia); Centeno and Marquez (2020), investigated the loss of the tourism industry in the Philippines, Correa-Martínez et al. (2020) investigated the spread of the virus in the ski area in Austria. In his commentary, Nepal (2020), centered on the impacts on Nepal.

\section{Methodology}

The study entirely based on secondary data collected from different secondary sources. More specifically, data were collected from UNWTO and also WTTC related tourist arrivals, tourism receipts, air reservation, hotel booking and occupancy rate. The Table 2 below elaborates the variables considered in the current study.

The collected secondary data were descriptively analyzed using graphs and tables in order to accomplish the objectives of the study.

\begin{tabular}{|l|l|l|}
\hline \multicolumn{1}{|c|}{ Table 2: Explanation of variables } \\
\hline Variable & & Explanation \\
\hline Tourist arrivals & $\begin{array}{l}\text { Number of visitors who stay at least one night in a collective or } \\
\text { private accommodation in the country visited }\end{array}$ & UNWTO \\
\hline Tourism receipts & Earnings from tourism industry & UNWTO and WTTC \\
\hline Air reservation & All airline reservation which are recorded in the reservation system & UNWTO \\
\hline Hotel bookings & Number of hotel bookings & UBWTO \\
\hline Occupancy rate & Percentage of available rooms sold during a specified time period & UNWTO \\
\hline \multicolumn{2}{|l}{ Source: Created by authors } \\
\hline
\end{tabular}

\section{Results and discussion}

\subsection{Impact on tourist arrivals and tourism receipts}

International tourist arrivals can be considered as one of the key measures which indicates smoothness of international tourism. The Figure 1 depicts region-wise drop in international tourist arrivals during the months of 2020 compared to 2019. According to the figure, international tourist arrivals at global level has decreased by $68.6 \%$ on average by 2020 compared to 2019. International tourist arrivals to Europe, America and Middle East have shown a negligible increase during the first two months of 2020 and however, region-wise international tourist arrivals have sharply declined after February, 2020. 


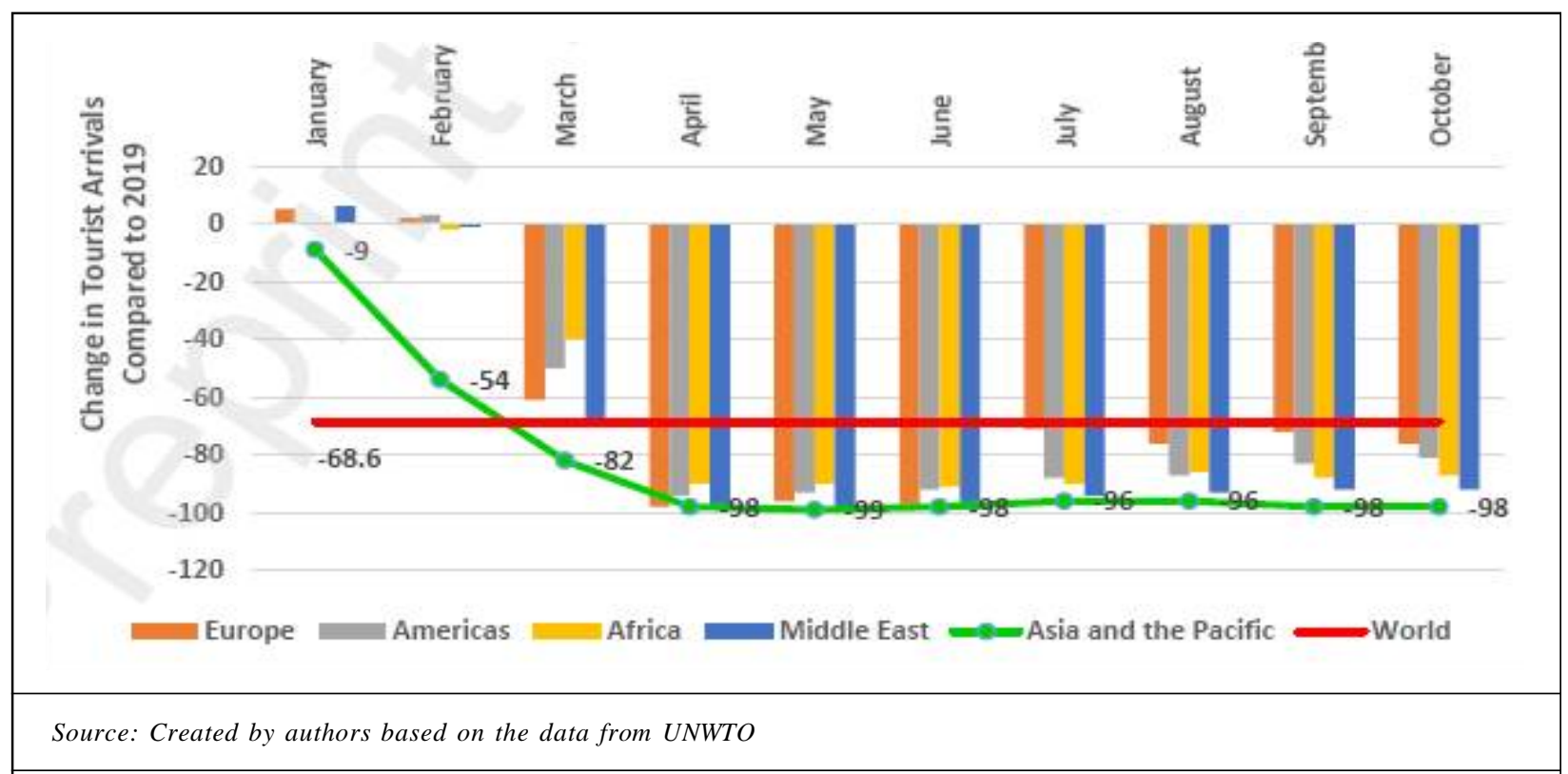

Figure 1: Change in tourist arrivals by 2020 compared to 2019

In general, all most all regions have reported more than 70\% drop in tourist arrivals since March 2020 compared to previous year, which is significantly higher than the average drop at global level (68.6\%). However, drop of international tourist arrivals in Europe has gradually declined till July, 2020 and has again shown a slight increase during the period of August to October, 2020. In contrast, drop of tourist arrivals to region such as Americas, Africa, Middle East and Asia and the Pacific has been stable and more than 80\% compared to 2019. More specifically, Asia and the Pacific region which was first affected by the Covid-19 has reported the highest drop in tourist arrivals, which was -9\% in January, 2020 and dropped further down to $-98 \%$ by October, 2020. Therefore, it is apparent from the Figure 1 that international tourist arrivals to all regions have drastically affected by the Covid-19 and the impact on Asia and the Pacific region is more substantial. In particular, subregions of the Asia and The Pacific such as North-East Asia (-83\%), South-East Asia (64\%), Oceania (58\%) and South Asia (55\%) have reported record-low arrivals of international tourists during the outbreak. In fact, world-wide lockdown and travel restrictions essentially discouraged travel across the world. Apart from that, declining the confidence of travelers and consumers and drop in disposable income due to loss of jobs due to Covid-19 drastically affected tourism industry across the globe.

Figure 2 provides a comprehensive country level analysis on Asia and the Pacific region in terms of tourist arrivals. According to the Figure 2, all selected 20 countries shows a dramatic decline in international tourist arrivals in 2020

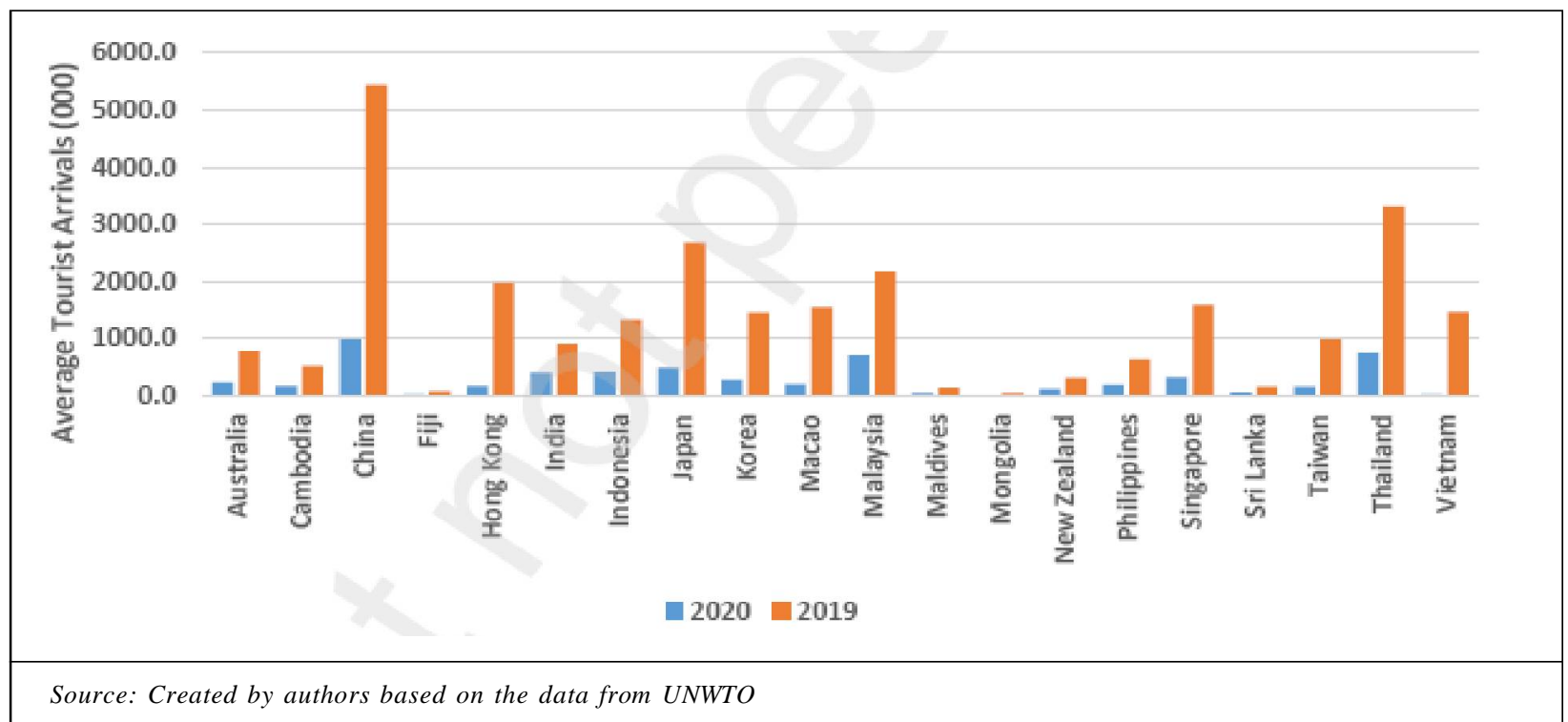

Figure 2: Country-wise comparison in tourist arrivals of Asia and the Pacific region during 2019-2020 
compared to 2019. Similarly, Figure 3 illustrates the country-wise growth rate of international tourist arrivals in 2020 compared to 2019. China has welcomed by far the largest international tourist in both 2019 and 2020 and however as Figure 3 indicates international tourist arrivals to China have dropped by $82 \%$ compared to 2019. Apart from that, countries such as Thailand, Japan, Malaysia and Hong Kong have also accounted for significantly higher level of international tourist arrivals in 2019 and however arrivals in 2020 have dropped by $78 \%, 82 \%, 67 \%$ and $92 \%$ respectively.

Moreover, drop in growth rate of tourism arrivals is more substantial in the countries such as Vietnam (-98\%), Hong Kong (-92\%), Mongolia (-90\%), Macao (-87\%) and Taiwan (-84\%) and also the drop of growth rate is considerably higher than that of world average $(-68.6 \%)$. Sharp drop in international tourist arrivals drastically affected the earnings from tourism industry in all over the world and the situation is more pathetic in the Asia and Pacific region. According to UNWTO (2020), massive drop in international travel demand has caused declining international tourist arrivals by 705 million and therefore earning from tourism has slashed by $\$ 730$ bn by August 2020 and this reduction is eight times higher than the income loss of 2009 during the global economic and financial crisis. Figure 4 depicts the quarterly change in tourism receipts received by 20 selected Asia and the Pacific countries in 2020 compared to 2019. As Figure 4 illustrates, all 20 countries have faced a sever reduction in tourism receipts received in 2020 compared to 2019. The reduction of tourism receipts is more considerable in the second quarter compared to the first quarter in most of the countries. More specifically, countries such as Vietnam, Sri Lanka and Malaysia have experienced 100\% reduction in tourism receipts in the second quarter of 2020 compared to the period in 2019. In fact, outbreak of Covid-19 was more wide-spread in early part of the second quarter and therefore many countries totally restricted tourism by imposing international travels and closing down the airport. Consequently, earning from tourism was severely dropped during the second quarter. Conversely, countries such as Japan, Macao, Malaysia, Singapore, Taiwan and Vietnam has shown slightly improvement of receiving tourism receipts during the third quarter of 2020. However, in general adverse impact of Covid on tourism receipt is significantly higher and will continue during 2021 as well.

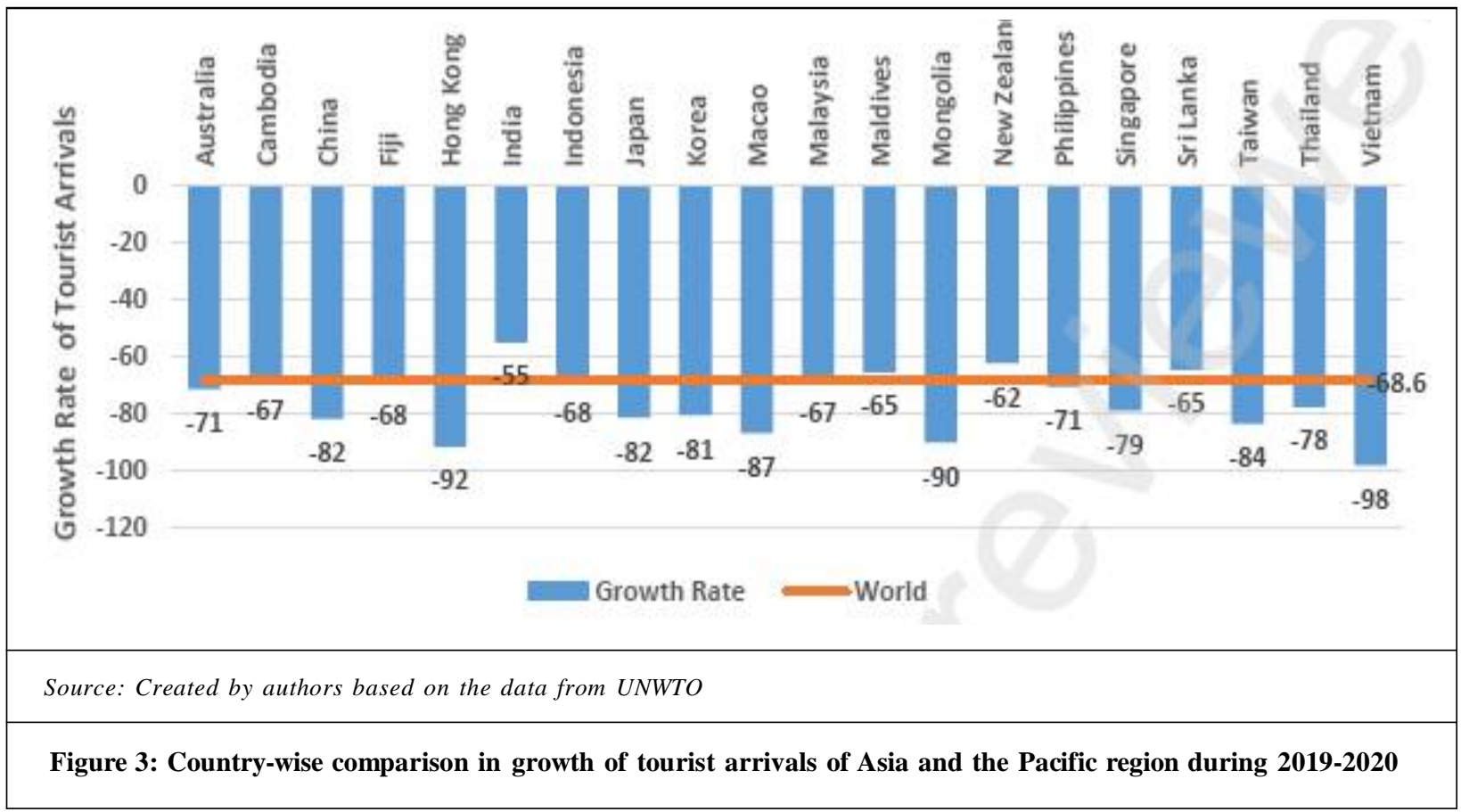

\subsection{Impact on air passenger reservation, occupancy rate and hotel bookings}

Drop in international travels has drastically affected international flight reservation. According to UNWTO (2020), global demand for air travel declined by $67 \%$ during the period of January-July 2020 and it's a $92 \%$ decline compared to July 2019. Figure 5 clearly illustrates the changes in flight reservation during the months of 2020 compared to 2019. According to the Figure 5, the global flight reservation has been declining since January 2020 compared to the previous year and decline is more substantial after February 2020. Further to UNWTO (2020), this figure also indicates that global flight reservation has decreased by $78.9 \%$ on average during the period of January to November 2020 compared to 2019. The region-wise flight reservation has reached a bottommost during the period of April-June 2020 and however there is a slight reduction of the drop since July 2020. 


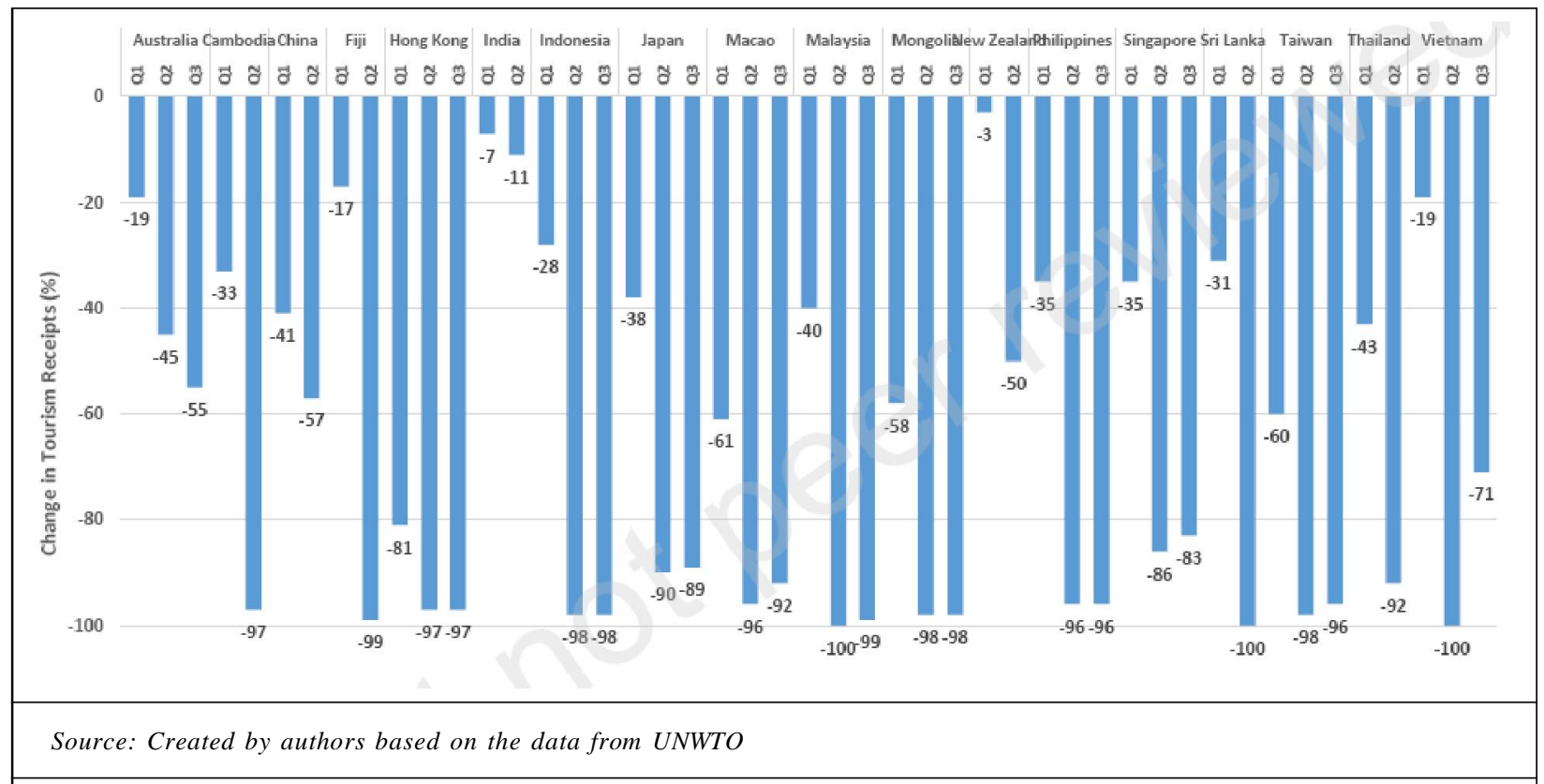

Figure 4: Quarterly change in tourism receipts of selected Asian and the Pacific countries compared to 2019

However, the drop of region-wise flight reservation is more than $80 \%$ throughout April to November 2020 compared to 2019. Particularly, Asia and the Pacific region has reported the highest drop (-96\%) in flight reservation by November 2020 compared to the previous year and therefore flight reservation of Asia and the Pacific region has been sharply affected by the Covid-19.

Apart from air passenger reservation, occupancy rate and hotel bookings can also be used to measure the impact of Covid-19 on tourism industry. Figure 6 compares the monthly occupancy rate of the Asia and the Pacific region between 2019 and 2020. According to Figure 6, the occupancy rate of the Asia and the Pacific in 2019 has varied between 65\%$74 \%$. However, the occupancy rate in 2020 has declined from 55\% in January to 27\% by March and has started increasing gradually after March. More specifically, the occupancy rate has increased from 29\% in April, 2020 to 58\% by October, 2020. However, it is apparent from the Figure 6 that occupancy rate of each and every month of 2020 is remarkably lower than that of 2019 .

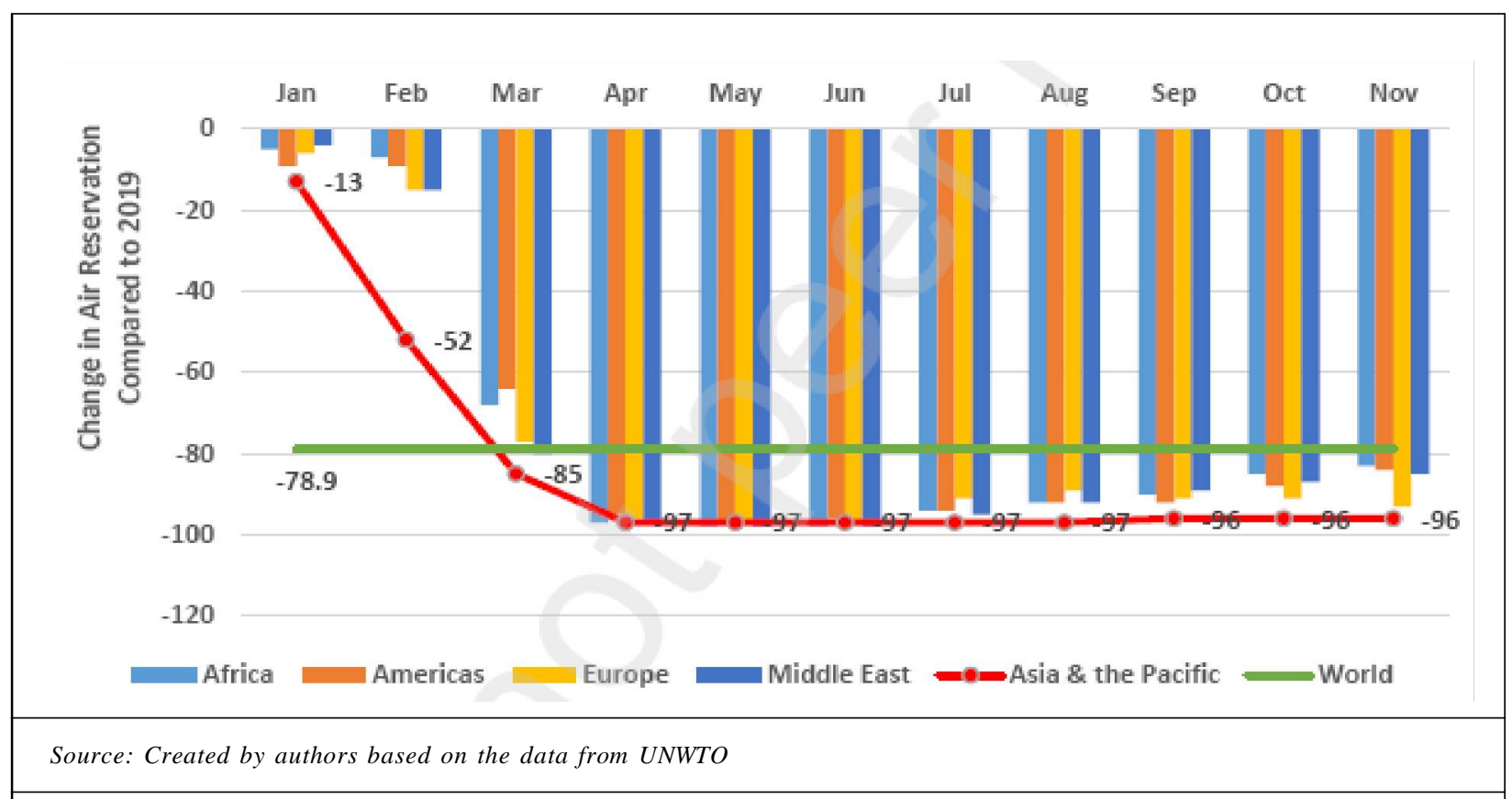

Figure 5: Change in air passenger reservation by 2020 compared to 2019 
Not only the occupancy rate, hotel bookings have also been severely affected by Covid-19. Figure 7 depicts the region-wise changes in hotel bookings of during the months of 2020 compared to 2019. According to the Figure 7, global average hotel bookings have declined by $46 \%$ in 2020 compared to 2019. Hotel bookings in Africa and Middle East regions have slightly increased during January and February of 2020 and however hotel bookings of all the regions have started declining continuously after February 2020.

Drop in hotel bookings has reached a bottom during April and May of 2020 and drop was more substantial in the regions such as Africa, Europe, Middle East and Asia and the Pacific. Despite all the regions have shown a gradual improvement in hotel bookings after May 2020, drops in hotel bookings of both Europe and Africa regions have again started increasing after July 2020 and the drop has exceeded the global average of $-46 \%$ in 2020. The pattern of drop in hotel bookings of the Asia and the Pacific region has been similar to the other region and however reported the third largest drop throughout 2020.
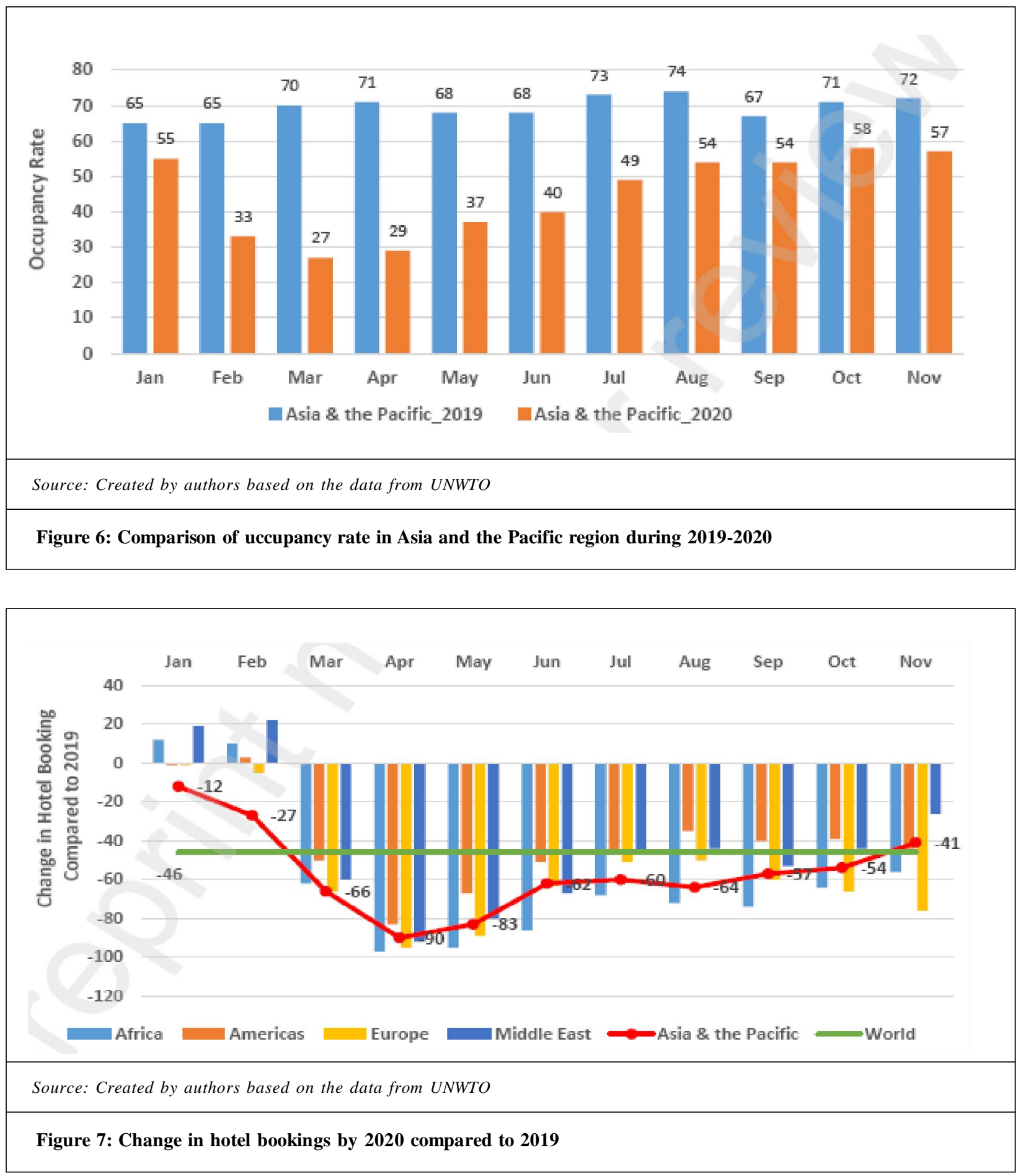


\section{Conclusion and Recommendations}

This paper examines the impacts of Covid-19 on tourism sector in the Asia and the Pacific region highlighting the impacts on tourist arrivals, tourism receipts, air reservation, hotel bookings and occupancy rates. The study focuses on 20 countries of the Asia and the Pacific region and the required data related tourist arrivals, tourism receipts, air reservation, hotel booking and occupancy rate were collected from UNWTO and also WTTC. As the results indicates, international tourist arrivals at global level has decreased by $68.6 \%$ on average by 2020 compared to 2019 . Moreover, international tourist arrivals to Europe, America and Middle East have shown a negligible increase during the first two months of 2020 and however, region-wise international tourist arrivals have sharply declined after February, 2020. In fact, Asia and the Pacific region which was first affected by the Covid-19 has reported the highest drop in tourist arrivals, which was $-9 \%$ in January, 2020 and dropped further down to $-98 \%$ by October, 2020 . More specifically, tourist arrivals to countries such as China, Thailand, Japan, Malaysia and Hong Kong have dropped by 82\%, 78\%, 82\%, 67\% and 92\% respectively in 2020 compared to 2019. Massive drop in international tourist arrivals caused declining global earnings from tourism sector by $\$ 730$ bn by August 2020 and this reduction is eight times higher than the income loss of 2009 during the global economic and financial crisis. The analysis further emphasized that all 20 countries have faced a sever reduction in tourism receipts in 2020 compared to 2019. The reduction of tourism receipts is more considerable in the second quarter compared to the first quarter in most of the countries and countries such as Vietnam, Sri Lanka and Malaysia have experienced $100 \%$ reduction in tourism receipts in the second quarter of 2020 compared to the period in 2019.

In addition to tourist arrivals and tourism receipts, air passenger reservation, occupancy rate and hotel bookings are also affected by Covid-19. The global flight reservation has decreased by $78.9 \%$ on average during the period of January to November 2020 compared to 2019 and the region-wise flight reservation has reached a bottommost during the period of April-June 2020 and however there is a slight reduction of the drop since July 2020. Particularly, Asia and the Pacific region has reported the highest drop (-96\%) in flight reservation by November 2020 compared to the previous year. Apart from that, the occupancy rate of the Asia and the Pacific in 2019 has varied between 65\%-74\%. However, the occupancy rate in 2020 has declined from 55\% in January to 27\% by March and has started increasing gradually after March. More specifically, the occupancy rate has increased from 29\% in April, 2020 to 58\% by October, 2020. Similarly, drop in hotel bookings has reached a bottom during April and May of 2020 and drop was more substantial in the regions such as Africa, Europe, Middle East and Asia and the Pacific. The pattern of drop in hotel bookings of the Asia and the Pacific region has been similar to the other region and however reported the third largest drop throughout 2020. It is apparent from the analysis that tourism sector at global level and particularly, in the Asia and the Pacific region has been affected by Covid-19 and however there is no guarantee that the outbreak will be over in 2021 . Hence, the study strongly recommends to explore possible ways of promoting tourism despite outbreak continues.

\section{References}

Abiad, A., Arao, R. M. and Dagli, S. (2020). The economic impact of the COVID-19 outbreak on developing Asia.

Baker, D.M.A. (2013). Understanding the economic impact of tourism in the Asian Pacific region using the tourism satellite account (TSA). ASEAN Journal on Hospitality and Tourism, 12(1), 3-14.

Centeno, R.S. and Marquez, J.P. (2020). How much did the tourism industry lost? Estimating earning loss of tourism in the Philippines. arXiv preprint arXiv:2004.09952.

Chen, R.J. (2011). Impacts of international tourism on economies in the Asia-Pacific region: opportunities and challenges. Tourism Analysis, 16(4), 499-503.

Correa-Martínez, C.L., Kampmeier, S., Kümpers, P., Schwierzeck, V., Hennies, M., Hafezi, W. and Mellmann, A. (2020). A pandemic in times of global tourism: superspreading and exportation of COVID-19 cases from a ski area in Austria. Journal of Clinical Microbiology, 58(6).

Dinarto, D., Wanto, A. and Sebastian, L.C. (2020). Global health security-COVID-19: impact on Bintan's tourism sector. RSIS Commentaries, 033-20.

Folinas, S. and Metaxas, T. (2020). Tourism: The great patient of coronavirus COVID-2019.

He, X., Lau, E. H., Wu, P., Deng, X., Wang, J., Hao, X., et al. (2020). Temporal dynamics in viral shedding and transmissibility of COVID-19. Nature medicine, 26(5), 672-675. 
Hoque, Ashikul., Farzana Afrin Shikha., Mohammad Waliul Hasanat., Ishtiaque Arif and Abu Bakar Abdul Hamid. (2020). The effect of Coronavirus (COVID-19) in the tourism industry in China. Asian Journal of Multidisciplinary Studies. 3(1) 52-58.

IATA (2020). International air transport association: Airlines financial monitor January - February 2020', Retrieved from: https://www.iata.org/en/iata-repository/publications/economic-reports/airlines-financial-monitor_feb-2020/

LePan, N. (2020). Visualizing the History of Pandemics. Visual Capitalist.

Moor, M. (2020). Tourism industry in Asia Pacific - statistics \& facts. Available: https://www.statista.com/topics/6107/ tourism-industry-in-asia-pacific/

Nepal, S.K. (2020). Travel and tourism after COVID-19-business as usual or opportunity to reset?. Tourism Geographies, $1-5$.

Pitlik, S.D. (2020). COVID-19 Compared to Other Pandemic Diseases. Rambam Maimonides Medical Journal, 11(3).

Travel and Tourism Competitiveness Index. (2019). Travel and Tourism Competitiveness Report. Available: https:// reports.weforum.org/travel-and-tourism-competitiveness-report-2019/regional-profiles/asia/

Uğur, N.G. and Akb1y1k, A. (2020). Impacts of Covid-19 on global tourism industry: A cross-regional comparison. Tourism Management Perspectives, 36, 100744.

UNWTO (2020). World Tourism Barometer, 18(1).

WTTC. (2020). Annual Report. World Travels and Tourism Council.

Cite this article as: Deyshappriya, N.P.R., U.G.O. Sammani and R.W.V.K. Minuwanthi (2021). Impact of Covid-19 on tourism sector of Asia and Pacific countries evidence from 20 Asia-Pacific countries. International Journal of Tourism and Hospitality. 1(2), 1-11. doi: 10.51483/IJTH.1.2.2021.1-11. 